International Journal of Trade $\mathcal{E}$ Commerce-IIARTC

July-December 2019, Volume 8, No. 2 pp. 341-347

(C) SGSR. (www.sgsrjournals.co.in) All rights reserved

Double Blind Peer Reviewed/Referred International Indexed Journal

ISRA JIF: 6.318; COSMOS (Germany) JIF: 5.135; ISI JIF: 3.721; NAAS Rating 3.55

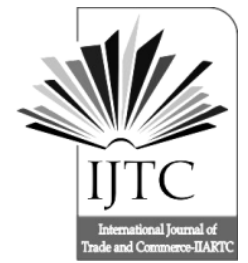

\title{
Investment Decision of Individual Investors in Delhi NCR
}

\author{
Aarzoo Sharma* \\ Department of Commerce and Management, J.V. Jain P.G. College, Saharanpur (U.P.) India \\ Email Id:shankeraarzoo@yahoo.com
}

\begin{abstract}
Individual's risk perception based on demographic factor such as gender, age, investment portfolio etc. Retail investor typically trade in much smaller accounts than institutional investors such as mutual funds, pensions etc. This paper makes a study of risk perception in investment decisions of individual investors especially in Delhi NCR.
\end{abstract}

Keywords: Investment portfolio, Risk and return management, investment pattern.

*Corresponding Author
PAPER/ARTICLE INFO RECEIVED ON: 02/09/2019 ACCEPTED ON: 29/11/2019

Reference to this paper should be made as follows:

Aarzoo Sharma (2019), "Investment Decision of Individual Investors in Delhi NCR", Int. J. of Trade and Commerce-IIARTC, Vol. 8, No. 2, pp. 341-347 
Investment Decision of Individual Investors in Delhi NCR

Aarzoo Sharma

\section{INTRODUCTION}

In Globalisation era finance plays a vital role. It is a valuable consideration for all significant decision making. Everyone knows the significance of saving. Investment involves proper channelizing of saving. In general, investments are the expenditure which is made in hope to gain some profit in future. Avram et al (2009) define the investment as "expenditure made now to make gains in future". The value of money also depreciates if it is not put to be invested; this is due to many factors such as value of money decreases with the passage of time. Money is the queen of all discoveries. Investment refers to the process of obtaining funds by building up operations or buying investment products such as stocks, bonds and annuities. Finance is discipline of managing funds by individuals, companies and the nation while investment is putting money aside in order to yield return. The process of investment decision encapsulates identification of problem, search for alternatives, evaluation of various option and constructing a portfolio. "Decision making under risk and uncertainty is one of biggest topics discussed by both psychologist and economist" (Lowenstein et al 2001)

The modern theory of decision making relating to investment under risk and uncertainty is very complication. According to Schumpeter, "it encompasses a far better claim to being referred as the logic of choice than a psychology of value. "Risk is a major element in the investment. Almost all investments are associated with some level of risk. Hence proper understanding of investment risk (financial risk) tolerance and risk management is essential in successful investment decisions. The assistance of financial advisors plays a vital role in their clients risk-related information during the advisory process.

\section{OBJeCTIVES}

To study the investment pattern in India.

To understand the behavioral biases of individual investor.

\section{LITERATURE REVIEW}

A review of literature consigns a research study in proper perspective by showing the quantity of work already carried out in the related area of the study. The purpose of this part is to understand the results of various studies already undertaken in the relevant field.

Jacob NiyoyitaMahina, Willy Mutori, Memb \& Florence (2017), Studied the effect of behavioural biases on investment in stock exchange. As per Kaur I and Kaushik (2016), Mutual fund in India is not a favourable investment alternatives as in developed countries. As per Thaler. R. (2016), A paradigm shift can happen due to the failure of orthodox ideas and policies or when new technology is introduced that radically alters the production process. Coffie William (2013), reveal the main issues of individual stock investors and examine whether there is any positive correlations between major stock investment strategies and behavioural finance theories. William N. Goetzmann and Alok Kumar (2008), Commented on diversified portfolio. Diversified choices of more than 60,000 individual investors were analyze at a large US discount brokerage house. Campbell John Y and John H. Cochrane (1999), Presented a consumption based model that explains the pro-cyclical variation of stock prices. Thaler R. (1985), framed a new model of consumer behaviour using a hybrid of cognitive psychology and micro economy. Kahneman D. and Trersky A. (1979), criticized the expected utility theory and an alternative model called 
prospect theory was developed. A prospect is a contract that yields outcome $\mathrm{n}$, with probability $\mathrm{P}_{\mathrm{i}}$, where $\mathrm{P}_{1}+\mathrm{P}_{2}+$ $. . P_{n}=1$.

Ogbulu (2018) investigated the impact of crude oil prices and foreign exchange rate movements on stock market prices in Nigeria. Yang Liu (2017), studied the implications of government debt for a net prices in the United States. Nguyen Linh T.M., Gullery G and Neuton (2016) showed the influence of financial risk tolerance on investment decision making. Dr. Shefali Dani and Riddhi Ambavale (2015) reflected the use of gold and all precious metals as a hedge against inflation, deflation or currency devaluation. It was found that gold and silver remained the most popular metals in India. Asani Sarkar (2006) described Indian Derivatives Market. A derivative enables trader to hedge some pre-existing risk by taking positions in derivatives market that offset potential losses in the underlying on spot market. Sharpe W C (1964) predicts the behaviour of capital market in the absence of a body of positive micro-economic theory dealing with conditions of risk. Friedman M, and 1.J. Sarage (1948) suggested that an important class of reactions of individuals to risk can be rationalized by a rather simple extension of orthodox utility analysis. He usually chooses certainty in preference to uncertainty.

Palash Bairagi and Anindita Chakraborty (2018) studied individual's risk perception based on demographic factor such as gender, age, income, investment portfolio and other demographic factor. Arvid O I Hoffimann and Thomas Post (2017) combined brokerage records and monthly matching measurements of a sample of individual investors from calendar months of April 2008 to March 2009 in Netherland to look the manner individual investors updated their beliefs and preferences as a result of their personal return and risk experience. Sandhu K P and Kumar R S (2014) analysed the relation between risk perception of the investors, in the Kerala State of India and the investment decision in Mutual Funds.

Julie R Agnew, Hazel Buteman Chrustine Eckert FedorIskhakov, Jordan Louviere, Susan Thorf (2018) assessed the quality of financial advice they reached and their formation of judgments about advisors distinguishing with the interaction between ordinary consumers and advisors. Gennaioli N, Shleifer A and Vishny R (2015) presented a model of investors delegating their portfolio management to professionals on the basis of trust. J Michael Collins (2012) explained how a lack of financial literacy can hamper the ability of individuals to make well informed financial decisions.

\section{RETAIL INVESTORS AND INVESTMENT AVENUES IN INDIA}

According to William defined an investor as "a buyer interested in dividends, or coupons and principal" (John Burr William, 1938)A retail capitalist is a private person who purchases securities for his or her own personal account instead for a corporation. Retail investor typically trade in much smaller accounts than institutional investors such as mutual funds, pensions or university in documents. They are non-professional investors. There are four channels of retail investing -

- Individual investors.

- $\quad$ Retail brokers (who act at the direction of those people)

- Managed accounts (whereby the account manager makes the buy and sell decisions for the individual) and

- Investment clubs (groups of individuals who pool their funds to create investment). 
Retail investors are further classified as active and passive. Active retail investors are the ones' who invest in equity market through primary market and secondary market directly, whereas passive investment to equity market is through mutual funds and pension funds. Retail investors do have a big impact on market sentiment with the fall in the brokerage fees, accessibility to more financial information, investment education and increase in trading tools than ever before, the participation of retail investors can be increased enormously. Samundra and Burghate (2012) saving of investment behaviour of individual investor has always been an area of interest to the economists and research. Investment avenues in India are classified as -

Low Risk Investment Avenues: Money Market Instruments, Non-Marketable Securities, Government Security (G-sec)

Moderate Risk Investment Avenues: Mutual Funds, Debentures or Bonds, Life Insurance and General Insurance

High Risk Investment Avenues: Equity Shares, Derivatives, Foreign Exchange Market, Commodity Market

Traditional Investment Avenues : Real Estate, Precious objects

\section{RISK AND RISK MANAGEMENT}

The literal meaning of the word risk is "to take the chance of something unpleasant happening". Risk is the chance of losing something of value. Uncertainties are undeniable part of any investment.

Campbell (2005, p. 569) described risk as expected harm. Risk perception is the ability of an individual to discern a certain amount of risk while risk tolerance refers to a person's capacity to accept the certain amount of risk. Risk perception is the subjective judgment that people make about the characteristic and severity of a risk. People perceiving of risks, processing of risk is information and way they make decision about them has been well explained through several theoretical models to be the psychometric paradigm, the risk perception model, social amplification of risk framework etc. Risk Management is essentially an entire method that involves the identification, evaluation and prioritization of risks followed by coordinated and economical application of resources to minimize, monitor and control the probability or impact of unfortunate events or to maximize the opportunities.

\section{Research Methodology}

The research primarily descriptive in nature and qualitative in approach. The research has used secondary data available on the sites of various stock exchange in India. The data for the study has also been collected from the site of stock exchange.

\section{ECONOMIC APPROACH TO INVESTOR BEHAVIOUR}

In economic theory of investment decision making, the investment decision of the individual investor is treated as a macro-economic aggregate and inter temporal of utility theory helps to draw its micro-economic foundation. The aim of investor is to maximize his expected utility based on wealth criteria while making a choice between consumption and investment through time. The theory assumes rational behaviour of investor. The theory of expected was introduced by Bernoulli, $\mathrm{D}$ in 1738. The expected utility is calculated by adding the weighted average of all possible outcomes with the weights being assigned by probability under certain situation. 
Traditional finance has dominance in the market. The body of knowledge was built on the pillars of arbitrage principles of Miller and Modigliani, the portfolio principal of Markowitz, capital assets pricing model (CAPM) of William sharps, Linter and Black and option pricing model of Black and Scholes, and Merton. (Statman, 1999)

Accordingly to these standard finances theories, people value wealth, investors act rationally while making financial decisions and investors would like to maximize their expected utility. Kahneman and Tversky $(1971,1979)$ and Slonic (1972) had challenged the rationality assumption and served the foundation for behaviour finance theories.

Behavioural Finance is thus, a combination of behavioural and cognitive psychological theory with conventional economics and finances. It is a sub field of behavioural economics, which proposes psychology based theories to explain stock market anomalies, such as, service rise or falls in stock price. It focuses upon how investors interpret and act on information to make informed investment decision. It was also found that either markets were not as efficient as once purported or that the asset during models were inadequate.

According to Pompian (2006), behavioural finance has two sub topics-

\section{Behavioural FinANCE Micro}

It analysis behaviour or biases of individual investors that distinguish them from the rational actors envisioned in classical economic theory.

Behavioural Finance Macro - It detects and describes anomalies in efficient market hypothesis that behavioural model may explain.

Types of Biases: Frame Dependent Biases : Prospect Theory, Loss Aversion, Mental accounting, Disposition Effect, Cognitive Dissonance, Regret Aversion

A. Heuristics and Biuses : Representatives, Overconfidence, Availability Bias, Anchoring, Endowment Effect, Conservatism

\section{CONCLUSION}

The aims to explore various dimensions of investment behavior. It also identifies the scope of retail investors and various investment avenues in India. It also emphasis on the need to study the risk associated with the investment along with the return. The role of behavioral finance is also highlighted. It was found that Indian investors are highly biased and avoid taking risk. The risk tolerance capacity of investors differ from individual to individual based on several psychological, behavioural and demographic factors. Proper Understanding of risk can enable them to make sound investment decisions.

\section{REFERENCES}

[1]. Agnew, Julie R, Hazel Bateman, Christine Eckert, Fedor Iskhakov, Jordan Louviere, and Susan Thorp, (2018). "First Impressions Matter: An Experimental Investigation of Online Financial Advice." Management Science, Vol. 64, No. 1, pp 288-307.

[2]. Asani Sarkar, (2006). "Indian derivative markets" The Oxford Companion to Economics in India, Available at http://www.newyorkfed.org/research/economists/sarkar/derivatives in India.

[3]. Avram E.L. et.al. (2009). Investment decisions and its appraisal, DAAAM International, Vienna, Austria, E.V., Vol. 20, No. 1, p. 1905-1906. 
[4]. Bairagi P. and Chakraborty A (2018). Influence of Risk Perception on Retail Investors Decision Making, Asian Journal of Management Vol. 9, Issue No. 2, ISSN-2321-5763.

[5]. Barberis, N, Huang, M and Santos, T, (2001), "Prospect theory and asset prices", Quarterly Journal of Economics, Vol. 116, No. 1, pp 1-53.

[6]. Beirberis, Nicholar and Richard Thaler, (2003), A Survey of Behaviour finance in hand book of the economics of finance, George M Constantices, ed Elsevie, Chapter 18, pp 10531123.

[7]. Bernoulli D., (1738). Exposition of a New Theory on the measurement of risk, translated by Louise Somner in Econometrica, 22 : 23-36.

[8]. Campbell S., (2005). Determining overall risk, Journal of risk research, 8(7-8) : 569-581.

[9]. Campbell, John $\mathrm{Y}$ and John H, Cochrane, (1999). "By force of habit : A consumption based explanation of aggregate stock market behaviour", Journal of political economy, CVII, 205251.

[10]. Coffie William (2013). Behavioural finance theories effecting on individual investor's decision making.

[11]. Collins, J. Michael, (2012). "Financial advice: A substitute for Financial Literacy?" Financial services Review, Vol. 21, No. 4, winter, pp. 307-322.

[12]. Eugene F Fama and Kenneth R French (2004). 'The capital asset pricing model : Theory and Evidence." Journal of economic perspective, volume 18, number 3, summer, PP 25-46.

[13]. Fama, E.F. and Mac Beth, J.D. (1973). 'Risk, return and equilibrium : Empirical tests', The journal of political economic, volume 81, number 3, pp american 607-636.

[14]. Friedman, Milton and Leonard J. Savage. (1948). "The Utility analysis of Chooices involving Risk Journal of Political Economy, August, 299-304.

[15]. Gennaiolo. N, Shleifer A, Vishny R. (2015) Money Doctors. J. Finance 70 (1): 91-114.

[16]. Goetzmann, W., Kumar, A., (2008). Equity portfolio, diversification review of finance, 12, 433-446.

[17]. Hoffman,, AO, Post, T (2017). How return and risk experiences shape investor beliefs and preferences. Accounting and Finance, 57 (3), 759-788.

[18]. Williams, J.B., (1938). The theory of Investment Value (Cambridge, Mass : Harvard Univesity Press), pp. 55-75.

[19]. Jacob Niyoyita Mahinu, Willy Muturi, Member Florence, (2017). Effect of Behavioural Biases on investments at the Rwanda Stock Exchange, International journal of Accounting, finance and risk management, Vol. 2, No. 4, pp. 131-137, doi : 10.11648/j.ijafam.20170204.11.

[20]. Jensen, Michael C. and black, Fischer and Scholes, Myron S, The capital Asset pricing model : some Empirical tests.

[21]. Kahneman, Daniel and Amos Tversky, (1979). Prospect theory, An analysis of division under risk, Econometrica, 47(2) : 263-292.

[22]. Kalecks, Michal (1937). The Principle of Increasing risk, Economica, Vol. 4 (New Series), 440-447.

[23]. Knight, F.H. (1921). Risk, uncertainty of Profit, Dover Publication, Mincoles N Y, 2006.

[24]. Lintner, John, (1965). The valuation of risk assets and the the reduction of risky investments in stock portfolio and capital budgets. Review of economic and statics 47, 13-37 
[25]. Liu, Yang, (2017). "Essays on Economic Uncertainty and Macro - Finance". Publicly Accessable Penn Dissertation. 2437 https://repository.upenn.edu/edissertations/2437.

[26]. Loewenstein, G. Weber, E.O., HSCE, C.K., I Welch, M. (2001), Risk as Feelings, Psychological Bulletin, 127(2), 267-286.

[27]. Markowtiz, H., (1952). "Portfolio Selection”, Journal of finance, 7(1), 77-91.

[28]. Modiglian, F, Miller, M. (1958). "The cost of capital, corporation Finance and the theory of investment." American Economic Review 48(3) 261-297. JSTOR 1809766.

[29]. Modigliani, F, Miller, M.H.(1963). Corporate income taxes and the cost of capital. A correction - the American Economic Review volume 53, number 3, pp 433-443,

[30]. Nguyen, Linh T.M.; Gallery; and Newton Camron, (2016). The influence of Financial Risk Tolerance on investment decision - Making in a Financial Advice context, Australasian Accounting, Business and Finance Journal, 10(3), 3-22, doi: 10.14453/aabfj.v.10;3.2

[31]. Pompian, Michel M (2006). Behavioural Finance and Wealth Management. John Wiley and Sons USA.

[32]. Samundra, Aparna \& Burghate, M.A. (2012). "A study of investment - Behaviour of middle class household in Nagpur", International Journal of Social Sciences and Inter disciplinary Research, Vol : 1, No. 5, pp. 30-41.

[33]. Schumpeter, J.A., (1954). History of Economic Analysis, New York, Oxford University Press.

[34]. Sekaran, V.(2003). Research methods for business. A Skill building approach, course smart, India.

[35]. Sharpe, W.F. (1964). Capital asset prices, a theory of Market equilibrium under conditions of risk - J. Finance 19: 425-442.

[36]. Shefali Dani and Riddhi Ambarate a value (2015). "A study of Investor's Preference and Risk and Return Analysis of Prectious Metals (Gold and Silver in India)" International Journal of Advanced Research in Management and Social Sciences, February, Vol. 4, Issue No. 2, PP 51-60.

[37]. Sindhu K.P. and Kumar, R.S. (2014). "Influence of risk perception of investors on investment decision : An empirical analysis", Journal of Finance and Bank Management, 2(2) : 15-25.

[38]. Statman Mavi (1999). Behavioral finance. Past Battles and Future Engagements Financial Analysis Journal (Nov.-Dec.) Vol.55:6, PP 18-27.

[39]. Subrata Mukherjee, (2011). "Risk minimization in spot and derivative market", International Journal of Research in Commerce and Management, Vol. 2, Issue 7 (July) 8792.

[40]. Thaler, R. (2016). Behavioural economics : Past, Present and Future, American Economics Review, 106(7), 1577-1600, doi : 10.1257/aer.106.7.1577.

[41]. Thaler, R., (1985). Mental accounting and consumer choice, Marketing Science, 4(3) : 194214. 